\title{
Nitrogen availability and mineralization in Pinus radiata stands fertilized mid-rotation at three contrasting sites
}

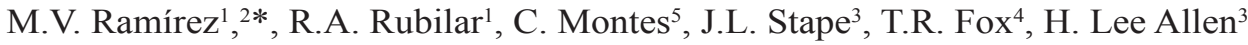 \\ ${ }^{1}$ Universidad de Concepción, Cooperativa de Productividad Forestal, Departamento de Silvicultura, \\ Facultad de Ciencias Forestales, Concepción, Chile. ${ }^{2}$ Bioforest S.A., Concepción, Chile. ${ }^{3}$ Forest Productivity \\ Cooperative, Department of Forestry and Environmental Resources, North Carolina State University, Raleigh, \\ NC 27695-8008, USA. ${ }^{4}$ Forest Productivity Cooperative, Department of Forest Resources and Environmental \\ Conservation, Virginia Polytechnic Institute and State University, Blacksburg, VA 24061, USA. *Corresponding \\ author:mairamirez@udec.cl. ${ }^{5}$ Warnell School of Forestry, Athens, GA 30602,USA.
}

\begin{abstract}
Fertilization of Pinus radiata plantations mid-rotation after thinning can alter soil nitrogen availability. However, the magnitudes and durations of tree and stand growth responses are not well understood across different soils with specific site conditions. Two mid-rotation fertilization trials in Pinus radiata plantations with unexpected sustained growth responses for more than 6 years and volume gains of $25 \mathrm{~m}^{3} \mathrm{ha}^{-1}$ and $50 \mathrm{~m}^{3} \mathrm{ha}^{-1}$ in sandy and granitic soil, respectively, and one trial with no response to fertilization were selected to study the monthly dynamics of nitrogen availability and net mineralization using in situ core incubations. After 2 years, the results showed that fertilization increased nitrogen mineralization and availability until 6 years in sandy soil and until 7 years in granitic soil following fertilization. This result explained the sustained stand growth response observed at these sites. When considering the magnitude of the response, large increases in mineralization rates and soil $\mathrm{N}$ availability were observed in the granitic soil relative to the sandy soil. Our results suggest that stands with available $\mathrm{N}-\left(\mathrm{NH}_{4}^{+}+\mathrm{NO}_{3}^{-}\right)$evels less than $2 \mathrm{~kg} \mathrm{ha}^{-1}$ during spring and fall months or with $\mathrm{N}-\left(\mathrm{NO}_{3}^{-}\right)$levels lower than $0.2 \mathrm{~kg} \mathrm{ha}^{-1}$ during any month may respond to $\mathrm{N}$ fertilization.
\end{abstract}

Keywords: Forest fertilization, nitrogen uptake, growth response, soil fertility, granitic, sandy, red clay

\section{Introduction}

Nitrogen $(\mathrm{N})$ rarely accumulates in inorganic soils over any significant duration (Johnson and Turner, 2014), and is the main element responsible for determining Pinus radiata productivity in several regions of the world. In Chile this is relevant because the forestry is the second productive sector, and Pinus radiata, is the specie with the highest surface and management (Alvear et al., 2008).

The supply of $\mathrm{N}$ depends on the decomposition rate of soil organic matter. This rate (net $\mathrm{N}$ mineralization) corresponds to the difference between the total $\mathrm{N}$ 
released (gross $\mathrm{N}$ mineralization) and the amount of $\mathrm{N}$ immobilized by soil microorganisms ( $\mathrm{N}$ immobilization) and is commonly used to refer to net increases or decreases in ammonium $\left(\mathrm{NH}_{4}^{+}\right)$and nitrate $\left(\mathrm{NO}_{3}^{-}\right)$concentrations (Schepers and Raun, 2008).

Some authors have found evidence of high nitrogen demand in other pine species with increasing stand competition (Allen et al., 1990). Nitrogen demand is maximized when canopy closure has occurred and is a function of the foliage developed by the stand (Turner and Lambert, 1986). Generally this demand coincides with decreasing soil $\mathrm{N}$ contents due to uptake by weed sand forest floor immobilization (Richter et al., 2000), which results in a lower volumetric forest growth (Albaugh et al., 2004). This result represents an opportunity to expect a positive mid rotation fertilization response (Carlyle, 1995) due to the increase in short term availability of $\mathrm{N}$ (Fox et al., 2007), as well as an increase in leaf area and foliage development (Rubilar et al., 2013).

The mineralization rate of organically-bound $\mathrm{N}$ depends on soil environmental factors, mainly soil organic matter content (Cartes et al., 2009), soil moisture and temperature (Khanna and Raison, 2013), and chemical and physical factors, which determine the potential supply rate of mineralizable N (O’Connell and Rance, 1999).

Carlyle (1995) and Raison et al. (1992) reported increasing $\mathrm{N}$ mineralization rates in response to mid rotation $\mathrm{N}$ fertilization. This increase is related to an increase in the $\mathrm{N}$ pool in the forest floor and the soil (Gurlevik et al., 2004). The forest floor positively impacts stand productivity and nitrogen availability when the nutrient availability increases (Zerpa et al., 2010).

The dynamics of processes related to the $\mathrm{N}$ pools in mineral soils are important for explaining the magnitude and duration of responses to mid rotation fertilization. In addition, $\mathrm{N}$ mineralization rate indexes have been used to estimate the potential responses of pine plantations to fertilization (Carlyle, 1995).

The stand growth response to nitrogen fertilization has been observed at several sites. However, its effects rarely persist for several years after applying fertilizer, which is mainly attributed to the lack of increase in the soil nitrogen budget over time. Typical responses in Pinus radiata stands last 3 to 5 years when $\mathrm{N}$ is applied at mid-rotation after thinning (Miller, 1981). However, these results differ from those obtained in mid-rotation fertilization studies developed for $P$. radiata stands in Chile, in which sustained responses were observed over time with volume increases of 7 $\mathrm{m}^{3} \mathrm{ha}^{-1} \mathrm{yr}^{-1}$ over 7 years in granitic soil and $4 \mathrm{~m}^{3}$ $\mathrm{ha}^{-1} \mathrm{yr}^{-1}$ over 6 years in volcanic sands (Table 1) (FPC, 2013). Given the nature of these long-term and sustained previously unreported responses, the objective of this study was to evaluate $\mathrm{N}$ availability, absorption and mineralization rates in fertilized and non-fertilized plantations and their interactions with soil moisture and temperature variables to predict responses of Pinus radiata to mid rotation fertilization in granitic and sandy soil. 
Table 1. Stand conditions for DBH, height, basal area and volume by soil type and treatment. The year of fertilization is indicated, and the percentage of gain evaluated in 2010. Values in parenthesis indicate $p$-value.

\begin{tabular}{|c|c|c|c|c|c|c|c|c|c|c|}
\hline Soil & Year & Treat. & $\begin{array}{l}\text { DBH } \\
(\mathrm{cm})\end{array}$ & $\begin{array}{l}\text { Gain } \\
(\%)\end{array}$ & $\begin{array}{c}\text { Height } \\
\text { (m) }\end{array}$ & $\begin{array}{l}\text { Gain } \\
(\%)\end{array}$ & $\begin{array}{c}\text { Basal area } \\
\left(\mathrm{m}^{2} \mathrm{ha}^{-1}\right)\end{array}$ & $\begin{array}{l}\text { Gain } \\
(\%)\end{array}$ & $\begin{array}{l}\text { Volume } \\
\left(\mathrm{m}^{3} \mathrm{ha}^{-1}\right)\end{array}$ & $\begin{array}{l}\text { Gain } \\
(\%)\end{array}$ \\
\hline \multirow{3}{*}{ Granitic } & 2003 & & 25.2 & & 18.5 & & 19.8 & \multirow{3}{*}{$\begin{array}{c}11.8 \\
(0.031) \\
\end{array}$} & 124.0 & \multirow{3}{*}{$\begin{array}{c}12.7 \\
(0.061) \\
\end{array}$} \\
\hline & \multirow{2}{*}{2010} & Control & 35.6 & 4.8 & 29.8 & -0.2 & 39.0 & & 391.1 & \\
\hline & & Fertilized & 37.4 & $(0.021)$ & 29.8 & $(0.937)$ & 43.6 & & 440.6 & \\
\hline \multirow{3}{*}{ Sandy } & 2004 & & 21.1 & & 15.5 & & 16.4 & \multirow{3}{*}{$\begin{array}{c}9.6 \\
(0.000)\end{array}$} & 86.8 & \multirow{3}{*}{$\begin{array}{c}11.7 \\
(0.002)\end{array}$} \\
\hline & \multirow{2}{*}{2010} & Control & 27.7 & 4.9 & 22.2 & 0.5 & 28.1 & & 210.0 & \\
\hline & & Fertilized & 29.1 & $(0.021)$ & 22.3 & $(0.697)$ & 30.8 & & 234.5 & \\
\hline \multirow{3}{*}{ Red-clay } & 2007 & & 23.7 & & 21.8 & & 19.3 & & 142.7 & \\
\hline & \multirow{2}{*}{2010} & Control & 28.1 & 0.4 & 25.1 & 0.3 & 26.9 & -0.2 & 231.3 & 0 \\
\hline & & Fertilized & 28.2 & $(0.671)$ & 25.2 & $(0.862)$ & 26.8 & $(0.941)$ & 231.4 & (0.99) \\
\hline
\end{tabular}

\section{Methodology}

\subsection{Study area}

The study sites are located in the Bío-Bío Region (Region VIII) in south-central Chile in three thinned Pinus radiata stands (average remaining stocking of 400 trees per hectare). The type of sites was granitic, sandy, red-clay, and the age was 12,13 and 15 years-old, respectively. The sites with granitic and volcanic sandy soil corresponded to second rotation stands that showed significant responses to mid-rotation $\mathrm{N}$ fertilization (Table 1). A second rotation at the red clay soil site with no fertilization response was considered.

The sites were chosen to consider a range of contrasting soil textures and parent materials. The climate at the study sites is Mediterranean with dry summers and rainfall that mainly occurs during the winter (June-August). Specifically, $65-70 \%$ of the annual total precipitation occurs during the winter and the remainder occurs during the autumn and spring.
The granitic site was located in the Coastal Range (36 39'0.72"S, 72 $44^{\prime} 52.08^{\prime \prime} O$ ). The annual mean temperature is $13.6{ }^{\circ} \mathrm{C}$ (6 years), with the monthly mean temperatures ranging from $8{ }^{\circ} \mathrm{C}$ in July to $17^{\circ} \mathrm{C}$ in January. In addition, the mean annual precipitation is $860 \mathrm{~mm}$ (35 years). The soils are classified as UlticPalexeralfs (Stolpe, 2006), are moderately drained, have a clay-loam texture, a bulk density of $1.3 \mathrm{~g} \mathrm{~cm}^{-3}$, a $\mathrm{pH}$ of 5.5 , an organic matter content of $7 \%$, a total $\mathrm{N}$ content of $0.1 \%$ and a $\mathrm{C}: \mathrm{N}$ of 25 .

The sandy soil site (volcanic sands) was located in the Central depression of Chile (37 $9^{\prime} 47.88^{\prime \prime} \mathrm{S}$, $72^{\circ} 14^{\prime} 17.53$ ' $O$ ), where the annual mean temperature is $13.6{ }^{\circ} \mathrm{C}$ ( 15 years), the monthly mean temperature ranges from $6{ }^{\circ} \mathrm{C}$ to $20{ }^{\circ} \mathrm{C}$, and the annual mean precipitation is $1319 \mathrm{~mm}$ (35 years). The soils are classified as Typic Xeropsamments (Stolpe, 2006) and are well-drained, with a sandy texture, a bulk density of $1.45 \mathrm{~g} \mathrm{~cm}^{-3}$, a pH of 6.2 , an organic matter content of $2.7 \%$, a total $\mathrm{N}$ content of $0.06 \%$, and a C: $\mathrm{N}$ of 22 . The red clay site (ancient volcanic ash) is located in the Central depression (37 $48^{\prime} 46.80^{\prime}$ 'S, 
$72^{\circ} 19^{\prime} 30.00$ 'O). The mean annual temperature is $13{ }^{\circ} \mathrm{C}$ (35 years), the monthly mean temperature ranges from $6.5{ }^{\circ} \mathrm{C}$ to $19{ }^{\circ} \mathrm{C}$, and the mean annual precipitation is $1254 \mathrm{~mm}$ (35 years). The soils are classified as Xeric Paleumults (Stolpe, 2006) and are well drained to moderately drained with a bulk density of $1.01 \mathrm{~g} \mathrm{~cm}^{-3}$, a pH of 5.3, an organic matter content of $14 \%$, a total $\mathrm{N}$ content of $0.22 \%$, and a C: $\mathrm{N}$ of 32 .

\subsection{Experimental design}

An incomplete factorial experimental design was used with 4 blocks and 0.36-ha $(60 \times 60 \mathrm{~m})$ treatment plots (internal measurement plots of $30 \times 30 \mathrm{~m}$ ). The 8 treatments included a control (no fertilization), the application of $8 \mathrm{~kg} \mathrm{~B} \mathrm{ha}^{-1}+65 \mathrm{~kg} \mathrm{~K} \mathrm{ha}^{-1}$, and a factorial combination of 2 levels of $\mathrm{N}$ (150 and $300 \mathrm{~kg} \mathrm{~N} \mathrm{ha}^{-1}$ ) and 3 levels of $\mathrm{P}\left(0,20\right.$ and $\left.40 \mathrm{~kg} \mathrm{P} \mathrm{ha}{ }^{-1}\right)$ with a base of $8 \mathrm{~kg} \mathrm{~B} \mathrm{ha}^{-1}+65 \mathrm{~kg} \mathrm{~K} \mathrm{ha}^{-1}$. The fertilizer sources included urea $(46 \% \mathrm{~N})$, triple superphosphate $(20 \%$ $\mathrm{P})$, boronatrocalcite $(10 \% \mathrm{~B})$ and potassium chloride $(61.5 \% \mathrm{~K})$. Fertilizer was applied by hand broadcast in autumn, May- 2003 in the granitic soil, June-2004 in the sandy soil, and June-2007 in the red clay soil. At all sites, herbicides were applied before fertilization. Diameter at breast height (DBH), total height, basal area and volume were measured annually during the dormant season, and sustained responses were observed in the granitic and sandy soil for more than 5 years following the highest $\mathrm{N}$ doses application (Table 1). Both treatments, the control (not fertilized) and the maximum fertilization $\left(300 \mathrm{~kg} \mathrm{~N} \mathrm{ha}^{-1}+\right.$ $\left.40 \mathrm{~kg} \mathrm{P} \mathrm{ha}{ }^{-1}+8 \mathrm{~kg} \mathrm{~B} \mathrm{ha}^{-1}+65 \mathrm{~kg} \mathrm{~K} \mathrm{ha}^{-1}\right)$ treatment, hereafter fertilized treatment, were selected to evaluate $\mathrm{N}$ availability pools, and soil/site temperature and moisture dynamics over 23 months (Feb 2010-Dec
2011) in sandy and granitic soil and over 27 months (Aug 2010- Oct 2012) in the red clay soil.

\subsection{Soil moisture and temperature}

Soil moisture and temperature sensors (Decagon Echo2 EC20, Hobo S-UCD-M0001, respectively), were used in the $0-15 \mathrm{~cm}$ soil layer at each site from September 2010. Data were stored hourly in a Hobo Micro station Data logger (H21-002). Gravimetric moisture content samples $\left(105{ }^{\circ} \mathrm{C}\right.$ for 24 hours) were obtained periodically to calibrate the soil moisture sensors at each site. Because this study began in February 2010 and the sensors were installed in September 2010 (granitic and sandy soil), the initial soil data (Feb 2010-Aug-2010) were modeled to obtain continuous data for the duration of the study. The mean air temperature was used to estimate the mean soil temperature by using climatic data and the field soil temperatures $[1,2]$. The regression model that were fit for the granitic soil was

Soil $\mathrm{T}=0.6936 *$ Env. $\mathrm{T}+3.1592 \quad\left(\mathrm{R}^{2}=74 \%\right)$

and for the sandy soil was

$$
\text { Soil } \mathrm{T}=0.915 * \text { Env. } \mathrm{T}+2.1014 \quad\left(\mathrm{R}^{2}=86 \%\right)
$$

Where Soil T is the soil temperature $\left({ }^{\circ} \mathrm{C}\right)$ and Env. T is the environment temperature $\left({ }^{\circ} \mathrm{C}\right)$.

The maximum and minimum mean temperatures, and precipitation were used to fit the soil moisture content using the Soil temperature and moisture model $\left(\mathrm{STM}^{2}\right)$ (USDA) (Perreault et al., 2013). Then, moisture estimates were adjusted (calibrated) using 
the field data $[3,4]$. The regression model that were fit for the granitic soil was

Soil moisture $=0.505 *\left(S T M^{2}\right)+0.0524\left(R^{2}=93 \%\right)$

and for the sandy soil was

Soil moisture $=0.7545 *\left(S T M^{2}\right)-0.0352\left(R^{2}=88 \%\right)$

Where Soil moisture is the soil moisture content $\left(\mathrm{cm}^{3} / \mathrm{cm}^{3}\right)$, and STM ${ }^{2}$ is the value obtained from the reference model $(\mathrm{cm} 3 / \mathrm{cm} 3)$ for each site. Finally, the soil moisture was converted to percentage (\%) using the bulk density for each site. The soil water retention curve and soil water holding capacity for each site were determined using a pressure-plate extractor (Richards and Fireman, 1943).

\subsection{Nitrogen availability, net mineralization and uptake}

The in situ incubation method described by Raison et al. (1987) was used to estimate the availability, uptake and net mineralization of nitrogen in the field. Each month, pre-incubated mineral soil samples $(0-$ to $15-\mathrm{cm})$ were collected and composited by plots from five random locations (mineral or available N). Simultaneously, five polyvinyl chloride (PVC) tubes were installed into the soil with minimal soil disturbance, and five more tubes were installed and sealed to prevent leaching. The soil in the tubes were left in the field to incubate for one month. This allows the estimation of net $\mathrm{N}$ mineralization as the change in the mineral- $\mathrm{N}$ content in the covered confined soil minus the soil mineral-N content at the start of the field incubation period. A negative value of net $\mathrm{N}$ mineralization reflects immobilization of $\mathrm{N}$ during the period of incubation. Differences in mineral-N content between the covered and uncovered (exposed) soils give a measure of maximum $\mathrm{N}$ leaching. Finally, the $\mathrm{N}$ uptake by plants is calculated as net $\mathrm{N}$ mineralization minus the amount of mineral-N present in the unconfined soil at the end of the field incubation, minus any losses of mineral $\mathrm{N}$ due to leaching (Khanna and Raison, 2013).

Composite pre-incubation and post-incubation samples were taken to the laboratory and maintained at $4{ }^{\circ} \mathrm{C}$ until extraction. The annual site nitrogen availability was calculated by adding the monthly $\mathrm{N}$ availability estimates, and the annual site net $\mathrm{N}$ mineralization and uptake was calculated as a result of adding the monthly values for net $\mathrm{N}$ mineralization and $\mathrm{N}$ uptake, respectively.

\subsection{Laboratory analysis}

Soil samples were maintained under field moist conditions to avoid $\mathrm{N}$ transformations, and $20 \mathrm{-g}$ subsamples were subjected to $\mathrm{NH}_{4}^{+}$(ammonium) extraction by using $50 \mathrm{~mL}$ of $2 \mathrm{M} \mathrm{KCl}$ (Mulvaney et al., 1996). In addition, $\mathrm{NO}_{3}^{-}$(nitrate) concentrations were determined using $50 \mathrm{~mL}$ of $0.025 \mathrm{M} \mathrm{Al}_{2}\left(\mathrm{SO}_{4}\right)_{3}$ (Pulgarín and Naranjo, 2005). Soil suspensions were shaken for 1 hour, cool conditions $\left(3^{\circ} \mathrm{C}\right)$, and decanted on the same day for chemical analysis of the supernatant solutions. Extracts were analyzed for ammonium using an ammonia gas selective electrode with a permeable gas membrane, and nitrate was determined using an electrode with a replaceable sensing module containing an organic polymer membrane that was sensitive to nitrate. The $\mathrm{NH}_{4}^{+}$ and $\mathrm{NO}_{3}^{-}$concentrations were determined as $\mathrm{N}(\mathrm{N}-$ $\mathrm{NH}_{4}^{+}, \mathrm{N}^{-\mathrm{NO}_{3}}{ }^{-}$) and were converted to a per hectare basis using bulk density estimates obtained from the field samples. These analyses and chemical determinations were performed at the Soil Nutrition 
and Forest Productivity Laboratory at the Universidad de Concepción.

\subsection{Statistical analysis}

A longitudinal repeated measures analysis was conducted to evaluate the effect of fertilization on each component of $\mathrm{N}$ availability $\mathrm{N}-\mathrm{NH}_{4}^{+}, \mathrm{N}^{-\mathrm{NO}_{3}}$, and $\mathrm{N}-\left(\mathrm{NH}_{4}^{+}+\mathrm{NO}_{3}^{-}\right)$(Littell et al., 2006).

The following statistical model was used:

$$
Y_{i i k}=\mu+\alpha_{i}+\gamma_{k}+(\alpha \gamma)_{i k}+e_{i i k}
$$

Where

$\mathrm{Y}_{\mathrm{ijk}}$ is the monthly available $\mathrm{N}$ content $\left(\mathrm{kg} \mathrm{ha}^{-1}\right), \mu$ is the mean for treatment $\mathrm{i}$ at time $\mathrm{k}(\mathrm{F}), \alpha_{\mathrm{i}}$ is the effect for treatment, $\gamma_{k}$ is the effect for time (T), and $(\alpha \gamma)$ $i k$ is the effect for treatment $\times$ time interaction $(\mathrm{F} \mathrm{x}$ $\mathrm{T})$. In addition, $\mathrm{e}_{\mathrm{ijk}}$ is the random error associated with the measurement at time $k$ on the $j$ th subject that is assigned to treatment $i$.

The same analysis was used to evaluate the effect of fertilization on net $\mathrm{N}$ mineralization (ammonification, nitrification and net mineralization). The same statistical model [5] was used, but in this case $\mathrm{Y}_{\mathrm{ijk}}$ is the monthly net $\mathrm{N}$ mineralization $\left(\mathrm{kg} \mathrm{ha}^{-1}\right)$.

All longitudinal analysis was developed by using a mixed model that considered several variancecovariance structures for each variable, including compound symmetry (CS), first order autoregressive (AR(1)), and first order autoregressive structure with heterogeneous variances (ARH(1)). The Bayesian information criterion (BIC) was used to select the best fit to the data.
In order to explain monthly changes in $\mathrm{N}$ availability, a multiple regression with temperature and moisture was evaluated and fit with the data. Statistical analyses were performed using the SAS software (SAS, 2009b).

The annual cumulative $\mathrm{N}$ availability and uptake differences between treatments were calculated using a mean differences analysis with the JMP 8 statistical software (SAS, 2009a). All statistical analyses were evaluated using a $p$-value of $<0.1$ as a significance level.

\section{Results}

\subsection{Soil temperature and moisture}

Modeled and measured soil temperature and moisture values were similar in granitic and in sandy soil (Figures 1A, 1B, 1C, 1D). The soil temperature for the sandy soil showed the greatest daily variations between winter and summer $\left(4-22.7^{\circ} \mathrm{C}\right)$ (Figure 1D), while the temperature variations were lower in the granitic and red clay soils (Figures 1B, 1F). The sandy and granitic soil were below the permanent wilting point (PWP) for long periods during the summer months (December-April) (Figures 1A, 1C). Sandy soil showed the lowest water holding capacity (WHC) $(5.7 \%)$ of all studied sites, with sudden changes in soil moisture content after rainy or dry days (Figure 1C). The WHC of the granitic soil was $9.3 \%$, and the soil moisture contents lowly and gradually changed (Figure 1A). The red-clay soil had the highest WHC (15\%), with soil moisture contents above PWP during most of the seasons (Figure 1E). 


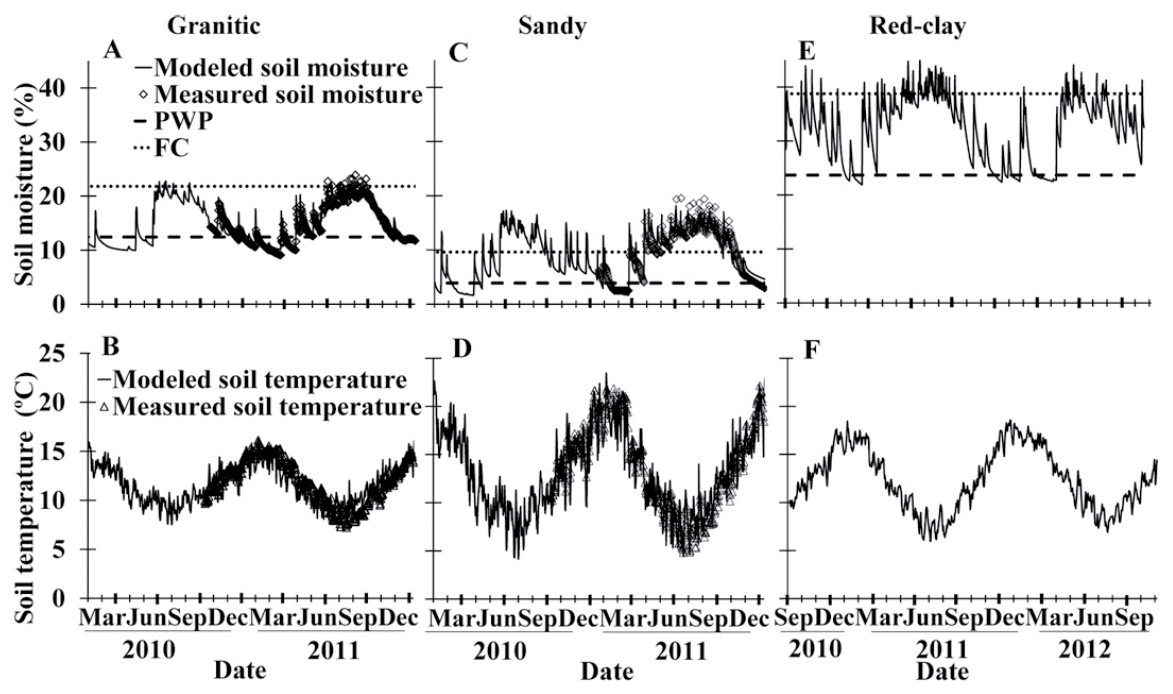

Figure 1. Average daily moisture content, permanent wilting point (PWP) and Field capacity (FC) in (A) granitic, (C) sandy, (E) red clay soil, and average daily temperature in (B) granitic, (D) sandy (F) red clay soil, for the surface 0 to $15 \mathrm{~cm}$ layer of mineral soil at mid-rotation Pinus radiata plantation.

\subsection{Nitrogen availability, mineralization and uptake}

\subsubsection{Monthly available nitrogen}

The fertilization by time interaction (F X T) treatment significantly affected the monthly nitrogen availability $\left(\mathrm{N}-\left(\mathrm{NO}_{3}^{-}\right), \mathrm{N}-\left(\mathrm{NH}_{4}^{+}\right)\right)$in the granitic, sandy and red clay soils $(p<0.1)$ (Table 2). During the study period, the available nitrogen $\mathrm{N}\left(\mathrm{N}_{-} \mathrm{NH}_{4}^{+}+\mathrm{N}^{+} \mathrm{NO}_{3}^{-}\right)$pools in the control treatment varied from 0.6 to $8.3 \mathrm{~kg} \mathrm{ha}^{-1}$ in the granitic soil (Figure 2A). The sandy soil ranged from 0.5 to $5.4 \mathrm{~kg} \mathrm{ha}^{-1}$ (Figure 2D), and the red clay soils ranged from 0.5 to $27 \mathrm{~kg} \mathrm{ha}^{-1}$ (Figure $2 \mathrm{G}$ ). For several months (August, September, November, December of 2010, and March, May, August of 2011), the average monthly available nitrogen in the control with red clay soil was higher than in the fertilized treatments with sandy and granitic soil (Figures 2A, 2D, 2G).
In April and July 2010, and August, September, October and November 2011, the fertilized treatment in granitic soil showed between 1.4 and 4.2 times more available nitrogen than the control $(p<0.1)$. During these months the monthly mean soil moisture content varied between $60-65 \%$ and $85-95 \%$ of the field capacity (FC) with monthly mean temperatures between 9.8 and $12.8{ }^{\circ} \mathrm{C}$. In April 2010, the soil moisture decreased and the mean soil temperature increased. Furthermore, April 2010 was the only month during which the available nitrogen in the fertilized treatment exceeded that of the control (4.5 times) for the sandy soil $(p<0.1)$, which coincided with a change in the soil moisture after a long dry period (less than PWP) and a mean temperature of $<12{ }^{\circ} \mathrm{C}$. 


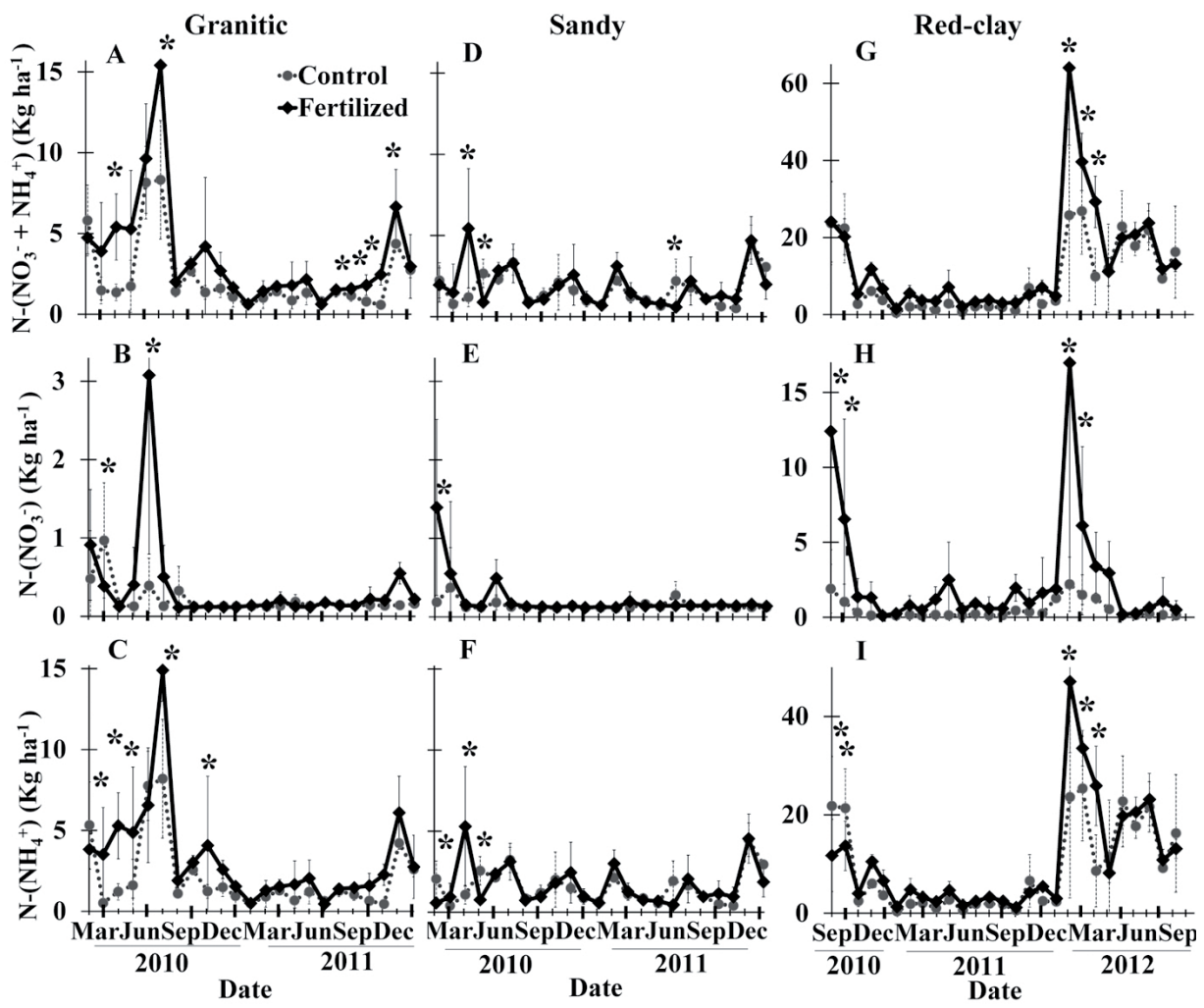

Figure 2. Monthly available mineral nitrogen $\mathrm{N}-\left(\mathrm{NH}_{4}^{+}+\mathrm{NO}_{3}^{-}\right), \mathrm{N}-\left(\mathrm{NO}_{3}^{-}\right), \mathrm{N}-\left(\mathrm{NH}_{4}^{+}\right)$in granitic $(\mathrm{A}, \mathrm{B}, \mathrm{C})$, sandy (D, E, F) and red clay soil (G, H, I) for the surface 0 to $15 \mathrm{~cm}$ layer of mineral soil from February 2010 to December 2011 (granitic, sandy), and from August 2010 to October 2012 (Red-clay soils) by treatment at midrotation Pinus radiata plantation. The asterisks indicate significant differences between treatments at the 0.1 probability level $(p$ value $<0.1)$.Error bars are plus or minus one standard deviation. 


\begin{tabular}{|c|c|c|c|c|}
\hline \multicolumn{5}{|c|}{ Available mineral nitrogen } \\
\hline Soil & Ef df & $\mathrm{N}-\left(\mathrm{NH}_{4}{ }^{+}+\mathrm{NO}_{3}{ }^{-}\right)$ & $\mathrm{N}-\left(\mathrm{NH}_{4}{ }^{+}\right)$ & $\mathrm{N}-\left(\mathrm{NO}_{3}{ }^{-}\right)$ \\
\hline \multirow{3}{*}{ Granitic } & $\begin{array}{ll}\mathbf{F} & 1\end{array}$ & 0.0064 & 0.0302 & 0.084 \\
\hline & T 22 & $<0.0001$ & $<0.0001$ & $<0.0001$ \\
\hline & FxT 22 & $<0.0001$ & 0.0083 & $<0.0001$ \\
\hline \multirow{3}{*}{ Sandy } & $\begin{array}{ll}\mathbf{F} & 1\end{array}$ & 0.6927 & 0.8236 & 0.0548 \\
\hline & $\mathbf{T} 22$ & $<0.0001$ & $<0.0001$ & $<0.0001$ \\
\hline & FxT 22 & 0.0003 & $<0.0001$ & 0.0066 \\
\hline \multirow{3}{*}{ Red-clay } & F 1 & 0.0411 & 0.1832 & 0.1312 \\
\hline & T 26 & $<.0001$ & $<.0001$ & $<.0001$ \\
\hline & FxT 26 & 0.0004 & 0.008 & 0.0004 \\
\hline \multicolumn{5}{|c|}{ Net nitrogen mine ralization } \\
\hline Soil & Ef df & $\begin{array}{c}\text { Net } \\
\text { mineralization }\end{array}$ & $\begin{array}{c}\text { Net } \\
\text { Ammonification }\end{array}$ & $\begin{array}{c}\text { Net } \\
\text { Nitrification }\end{array}$ \\
\hline \multirow{3}{*}{ Granitic } & $\begin{array}{ll}\mathbf{F} & 1\end{array}$ & 0.6396 & 0.9502 & 0.0004 \\
\hline & T 21 & $<0.0001$ & $<0.0001$ & $<0.0001$ \\
\hline & FxT 21 & $\mathbf{0 . 0 9 8 7}$ & 0.0363 & $<0.0001$ \\
\hline \multirow{3}{*}{ Sandy } & $\begin{array}{ll}\mathbf{F} & 1\end{array}$ & 0.2426 & 0.0589 & 0.2325 \\
\hline & T 21 & $<0.0001$ & $<0.0001$ & $<0.0001$ \\
\hline & FxT 21 & $<0.0001$ & $<0.0001$ & 0.0006 \\
\hline \multirow{3}{*}{ Red-clay } & $\begin{array}{ll}\text { F } & 1\end{array}$ & 0.3207 & 0.6703 & 0.0739 \\
\hline & T 25 & $<.0001$ & $<.0001$ & $<.0001$ \\
\hline & FxT 25 & 0.0015 & 0.0102 & 0.0027 \\
\hline
\end{tabular}

Table 2. Statistical summary of longitudinal repeated measures analysis to fertilization (F) and sampling date (T) effects on available mineral nitrogen pools, and net $\mathrm{N}$ mineralization in the surface 0 to $15 \mathrm{~cm}$ layer of mineral soil collected monthly from February 2010 to December 2011 (Granitic and Sandy soil), and from August 2010 to October 2012 (Red-clay soils) (Ef: Effect, df: Free degree). Due to sampling date for N mineralization began a month later (a month for incubation in situ) respect to $\mathrm{N}$ availability, degrees of freedom were different bettween $\mathrm{N}$ mineralization and $\mathrm{N}$ availability. Bold values highlighted represent significant level of $10 \%(p<0.1)$ 
By contrast, in February, March and April 2012, the fertilized treatment had 1.5 to 3 times more available nitrogen than the control $(p<0.05)$ in the red clay soils (Figure $2 \mathrm{G}$ ), which is equivalent to an excess of 13-38 kg ha-1 in the fertilized treatments relative to the control. These months (summer-autumn) had mean temperatures greater than $13{ }^{\circ} \mathrm{C}$, with important rainfall events and monthly mean soil moisture contents greater than $60 \%$.

Similar treatment and sampling date effects were observed when the extractable mineral $\mathrm{N}$ pool was partitioned into $\mathrm{N}^{-\mathrm{NH}_{4}}{ }^{+}$(ammonium) and $\mathrm{N}_{-} \mathrm{NO}_{3}{ }^{-}$ (nitrate) pools (Table 2) in granitic (Figures 2B, 2C), sandy (Figures 2E, 2F) and red clay soil (Figures 2H, 2I).

Available nitrogen dynamics were mainly driven by the $\mathrm{N}^{-\mathrm{NH}_{4}}{ }^{+}$behaviors in the fertilized and control

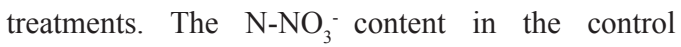
treatment exhibited small changes, which presented mild increases in the fertilized treatment $(p<0.1)$ for all sites (Figures 2B, 2E, 2H). In the red clay soil, the monthly $\mathrm{N}^{-} \mathrm{NH}_{4}^{+}$and $\mathrm{N}-\mathrm{NO}_{3}{ }^{-}$proportions were generally greater than those in the sandy and granitic soils (Figure 2).

The obtained multiple linear regression model [6], showed a strong relationship between the monthly mean soil temperature (Soil T) $\left({ }^{\circ} \mathrm{C}\right)$ and monthly mean soil moisture content (Soil mois) (\%), with the monthly $\mathrm{N}$ availability $\mathrm{N}-\left(\mathrm{NO}_{3}^{-}+\mathrm{NH}_{4}^{+}\right)$.

The obtained model between the variables was:

$\mathrm{N}-\left(\mathrm{NO}_{3}{ }^{-}+\mathrm{NH}_{4}{ }^{+}\right)=0.114 *$ Soil $\mathrm{T}+0.043 *$ Soil moisture $[6]$

Soil $\mathrm{T}$ and Soil moi sexplained $68.7 \%$ of the $\mathrm{N}$ availability when the granitic and sandy soil values, the sites with clear responses to fertilization were used (Table 3, and Figure 3). When the red clay soil was included, the model fit was poor and the parameters were not significant.

Table 3. Confidence interval (95\%) for estimates of the coefficients, and analysis of variance of the final revised model to monthly $\mathrm{N}$ availability to granitic and sandy soil

\begin{tabular}{lcccccc}
\hline \multicolumn{1}{c}{ Parameter } & Estimation & $\begin{array}{c}\text { Standard Lower } \\
\text { error }\end{array}$ & limit & Upper & limit & p-value \\
\hline $\begin{array}{l}\text { Mean soil } \\
\text { temperature }\left({ }^{\circ} \mathrm{C}\right)\end{array}$ & 0.1137 & 0.0193 & 0.075 & 0.152 & 0.0000 \\
$\begin{array}{l}\text { Mean soil } \\
\text { moisture }(\%)\end{array}$ & 0.0435 & 0.0203 & 0.003 & 0.084 & 0.0358 \\
\hline \hline & & Sum of & Mean & F & p- & $\mathbf{R}^{\mathbf{2}}$ \\
\multicolumn{1}{c}{ Source } & df & squared & squared & value & adjusted \\
\hline $\begin{array}{l}\text { Model } \\
\text { Residual }\end{array}$ & 85 & 326.89 & 163.445 & 94.72 & 0.000 & $68.70 \%$ \\
Total & 87 & 476.671 & 1.72554 & & & \\
\hline \hline
\end{tabular}




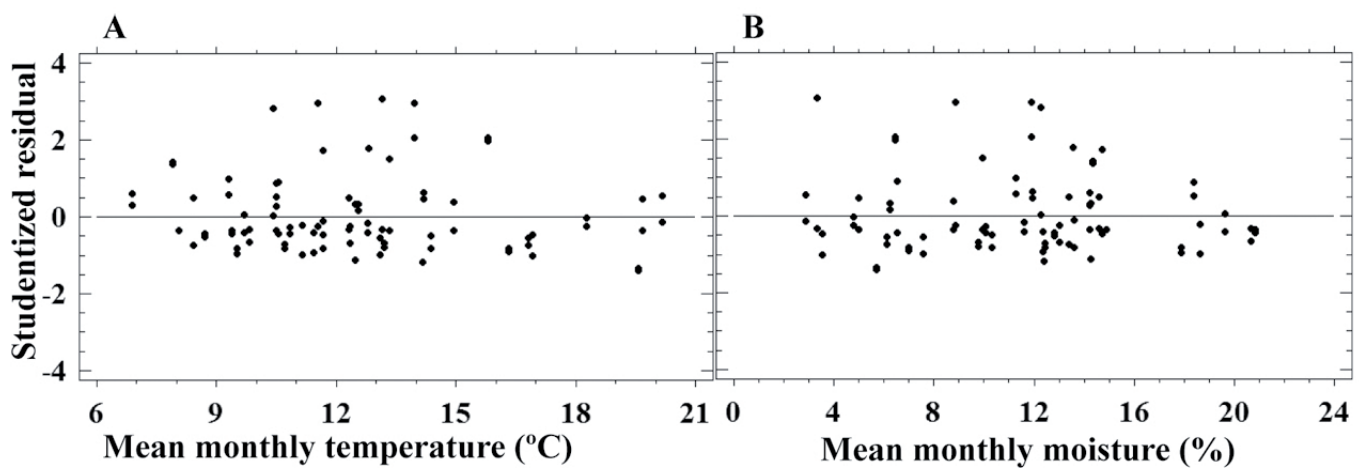

Figure 3. Studentized residual A) mean monthly temperature $\left({ }^{\circ} \mathrm{C}\right)$ and $\left.\mathrm{B}\right)$ mean monthly moisture (\%) to explain monthly $\mathrm{N}$ availability in granitic and sandy soil.

\subsection{Annual cumulative nitrogen availability}

The cumulative annual available $\mathrm{N}-\left(\mathrm{NH}_{4}^{+}+\mathrm{NO}_{3}^{-}\right)$ was lowest in sandy soil and highest in red clay soil every year (Figure 4). In addition, the cumulative available $\mathrm{N}-\left(\mathrm{NH}_{4}^{+}+\mathrm{NO}_{3}^{-}\right)$in the granitic soil was less than $35 \mathrm{~kg} \mathrm{~N} \mathrm{ha}^{-1} \mathrm{yr}^{-1}$ in the control. In contrast, the fertilized treatment showed a sustained increment compared with the control treatment even 7-8 years after fertilization, and the available nitrogen increased by $66 \%\left(58 \mathrm{~kg} \mathrm{ha}^{-1} \mathrm{yr}^{-1}\right)$ in the fertilized treatment in $2010(p<0.05)$ and by $48 \%\left(25 \mathrm{~kg} \mathrm{ha}^{-1} \mathrm{yr}^{-1}\right)$ in $2011(p<0.05)$ (Figure 4A). The cumulative nitrate in the fertilized plot exceeded that in the control treatment by $37 \%$ in $2011(p<0.05)$ (Figure 4B), and the cumulative ammonium in the fertilized treatment exceeded that in the control by $63 \%$ in 2010 and by $50 \%$ in 2011 (Figure 4C).

The cumulative available nitrogen $\mathrm{N}-\left(\mathrm{NH}_{4}^{+}+\mathrm{NO}_{3}^{-}\right)$ content was less than $20 \mathrm{~kg} \mathrm{~N} \mathrm{ha}^{-1} \mathrm{yr}^{-1}$ in the sandy soil, and no differences were observed in the fertilized treatments after 6-7 years (Figure 4D). Additionally, ammonium (Figure 4F) showed no significant differences between the treatment. However, the fertilized treatment had 2 times more nitrate than that in the control $\left(2 \mathrm{~kg} \mathrm{ha}^{-1}\right)$ in 2010 (Figure 4E) $(p<0.1)$. In 2010 (Aug-Dec), the red clay soil showed 6 times more annual cumulative nitrate in the fertilized plots relative to the control treatments. The annual cumulative available $\mathrm{N}$ (ammonium plus nitrate) and the ammonium were between 1.3 and 1.9 times greater in the fertilized treatment than in the control in 2011 and 2012 (Jan-Oct), (Figures 4G, 4I). The cumulative annual $\mathrm{N}$ contents in the red clay soils were greater than those at all other sites, even the control (red clay) exceeded the cumulative annual $\mathrm{N}$ contents with respect to the fertilized treatments in the granitic and sandy soils (Figure 4). 


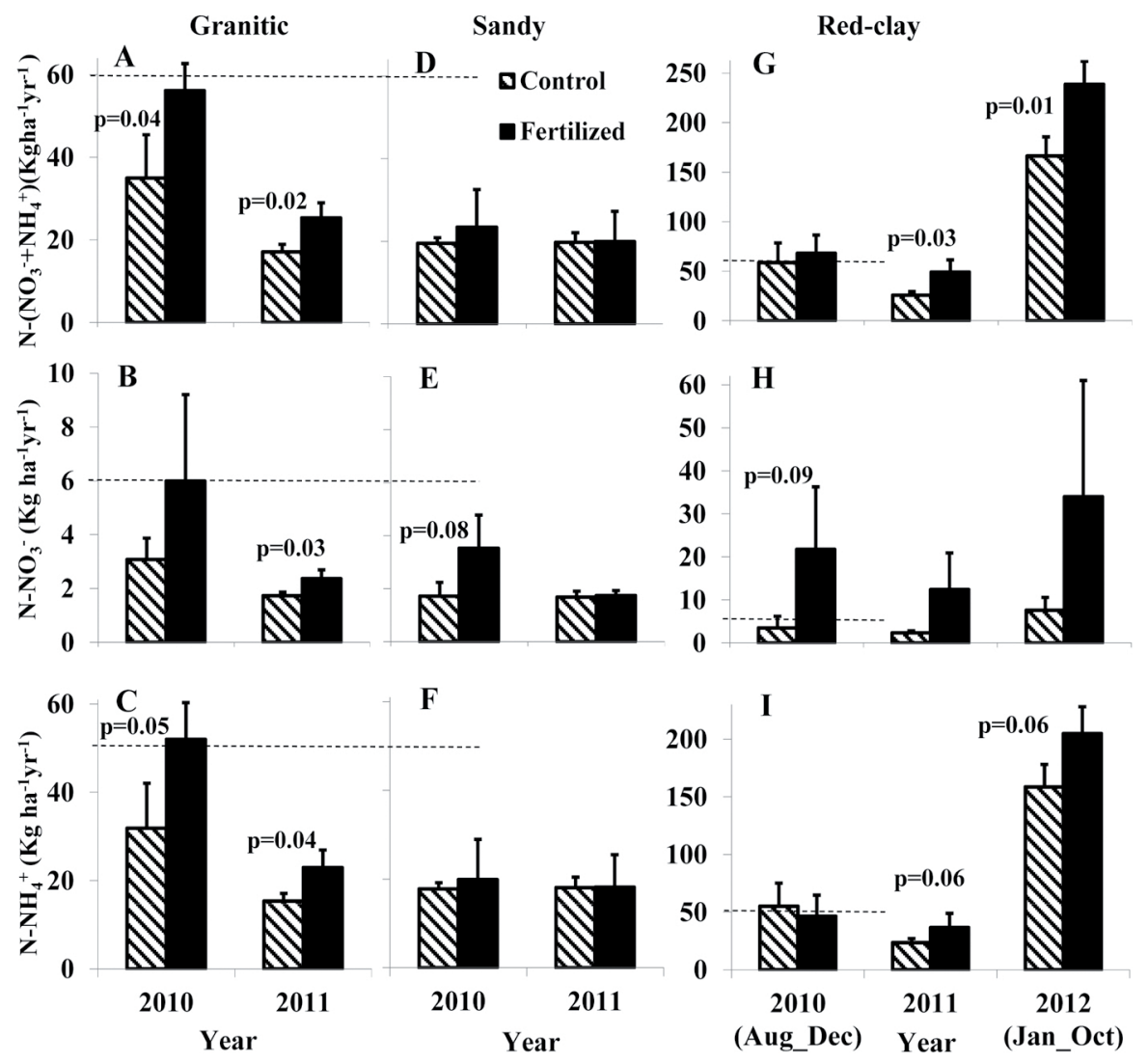

Figure 4. Annual cumulative available mineral nitrogen $\mathrm{N}-\left(\mathrm{NH}_{4}^{+}+\mathrm{NO}_{3}^{-}\right), \mathrm{N}-\left(\mathrm{NO}_{3}^{-}\right), \mathrm{N}-\left(\mathrm{NH}_{4}^{+}\right)$in granitic $(A$, $\mathrm{B}, \mathrm{C})$, sandy (D, E, F) and red clay soil (G, H, I) for the surface 0 to $15 \mathrm{~cm}$ layer of mineral soil summed from monthly values by treatment at mid-rotation Pinus radiata plantation. Error bars are plus one standard deviation.

\subsection{Monthly net $N$ mineralization}

The fertilization by time interaction(FXT) significantly affected nitrogen mineralization (ammonification, nitrification and net $\mathrm{N}$ mineralization) in the granitic, sandy and red clay soils $(\mathrm{p}<0.1)$ (Table 2). The treatment effect was highly variable at all sites for net ammonification processes relative to net nitrification. The red clay soil had the highest net $\mathrm{N}$ mineralization (ammonification and nitrification) rates (Figures 5G, 5I) and greater net nitrification (Figure 5H) relative to the other sites. This finding could be explained by the recent fertilization at this site. The monthly net nitrification in the granitic and sandy soils was less than $0.2 \mathrm{~kg} \mathrm{ha}^{-1}$ (Figures 5B,5E) in the control treatment. The net nitrification in the control treatment was less than that in the fertilized treatment during some months, reaching values of $12 \mathrm{~kg} \mathrm{ha}^{-1}$ month $^{-1}$ in the granitic soils, $7 \mathrm{~kg} \mathrm{ha}^{-1}$ month $^{-1}$ in the sandy soil, and $39 \mathrm{~kg} \mathrm{ha}^{-1}$ month $^{-1}(p<0.1)$ in the red clay soil (Figures 5C, 5F, 5I). At all sites, clear N immobilization patterns were observed (Figure 5G). 

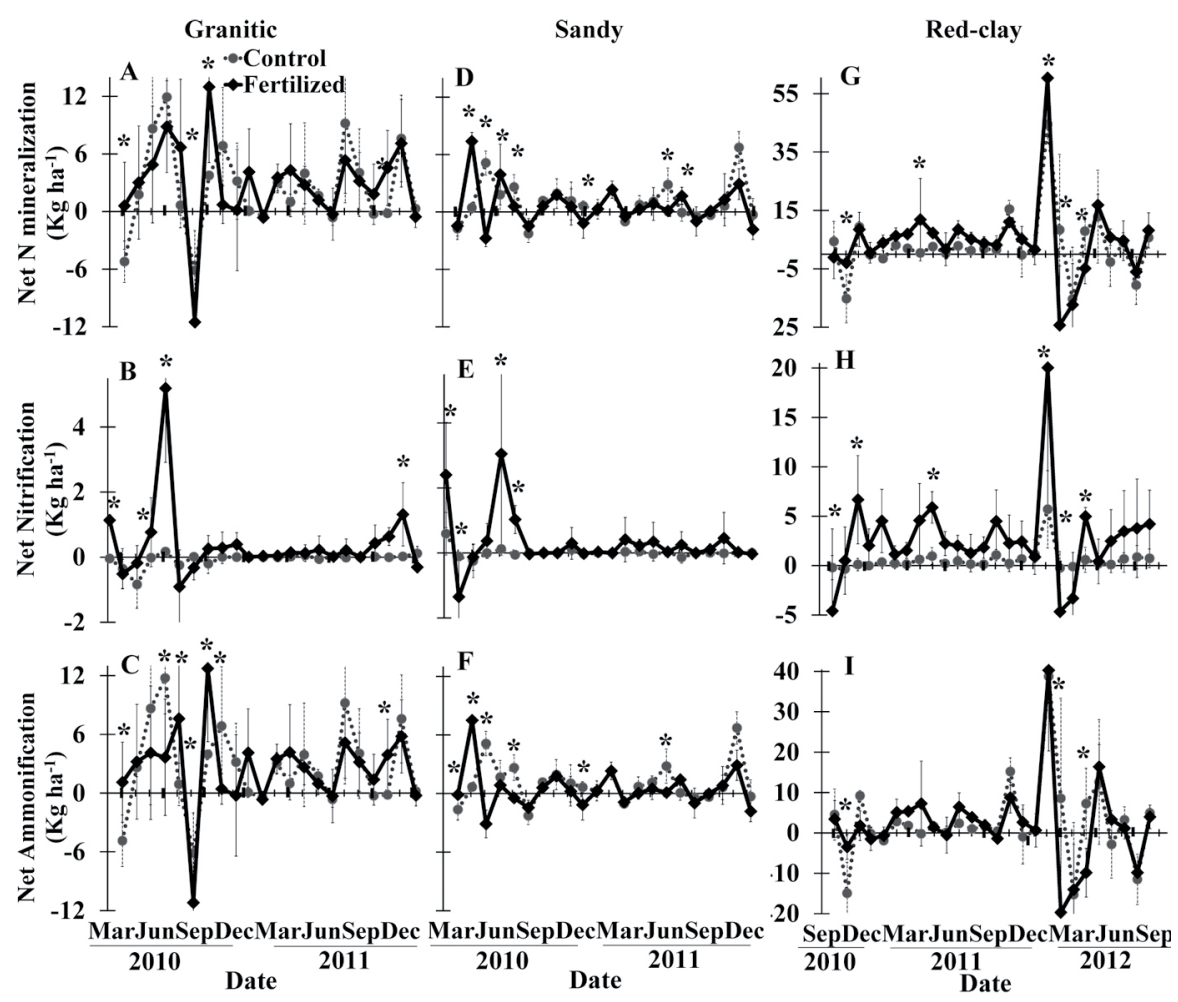

Figure 5. Monthly field estimates of net nitrogen mineralization, nitrification, and ammonification in granitic (A, B, C), sandy (D, E, F) and red clay soil (G, H, I) for the surface 0 to $15 \mathrm{~cm}$ layer of mineral soil from March 2010 through December 2011 (granitic, sandy) and from September 2010 to October 2012 (Red-clay soil) by treatment at mid-rotation Pinus radiata plantation. The asterisks indicate significant differences between treatments at the 0.1 probability level $(p$ value $<0.1)$. Error bars are plus or minus one standard deviation.

\subsection{Annual cumulative nitrogen uptake and mineralization}

The cumulative annual uptake of $\mathrm{N}$ for the treatments at each site was similar to the $\mathrm{N}$ availability in the granitic and sandy soils. Granitic soil had higher $\mathrm{N}-\mathrm{NO}_{3}^{-}$uptake in 2010, and higher $\mathrm{N}^{-} \mathrm{NO}_{3}^{-}, \mathrm{N}^{-} \mathrm{NH}_{4}^{+}$ and $\mathrm{N}-\left(\mathrm{NH}_{4}^{+}+\mathrm{NO}_{3}^{-}\right)$uptake in 2011 in the fertilized soil respect to the control treatment $(\mathrm{p}<0.1)$ (Table 4). The red clay soil had higher $\mathrm{N}_{-} \mathrm{NO}_{3}^{-}$uptake in the fertilized treatment relative to the control treatment in $2011(p<0.1)$ (Table 4) but in other years, no differences were observed between the treatments, despite the greater $\mathrm{N}$ availability in the fertilized plots (Figures 4G, 4H, 4I).

On an annual basis, no differences in ammonification or net nitrogen mineralization were observed between the granitic, sandy and red-clay soils treatments. However, net nitrification was significantly greater in the fertilized treatments with respect to the control in the granitic, sandy, and red clay soils $(p<0.1)$ (Table $4)$. The annual net nitrification was less than $0.4 \mathrm{~kg} \mathrm{ha}^{-1}$ 
$\mathrm{yr}^{-1}$ in the control treatment for sandy and granitic soil during the study (poor sites), and was greater than 5 $\mathrm{kg} \mathrm{ha}^{-1} \mathrm{yr}^{-1}$ (2011 and 2012) in the same treatment in the case of red clay soil (Table 4).

Table 4. Annual cumulative mean values to $\mathrm{N}$ uptake and to $\mathrm{N}$ net mineralization in the surface 0 to $15 \mathrm{~cm}$ layer of mineral soil collected monthly from February 2010 to December 2011 (Granitic and sandy soil), and from August 2010 to October 2012 (Red-clay soil) in Control (Cont) and Fertilized (Fert) treatments. Bold values highlighted represent significant level of $10 \%(p<0.1)$, and asterisks represent higher values in control respect fertilized treatment.

\begin{tabular}{|c|c|c|c|c|c|c|c|c|c|c|}
\hline \multicolumn{11}{|c|}{ Uptake } \\
\hline \multirow{3}{*}{ Soil } & \multicolumn{4}{|c|}{$\mathrm{N}-\left(\mathrm{NH}_{4}+\mathrm{NO}_{3}\right)$} & \multirow{2}{*}{\multicolumn{2}{|c|}{$\begin{array}{c}\mathrm{N}-\mathrm{NO}_{3}^{-} \\
\left(\mathrm{kg} \mathrm{ha}^{-1}\right)\end{array}$}} & \multirow{3}{*}{$\begin{array}{c}\mathrm{p}- \\
\text { value }\end{array}$} & \multirow{2}{*}{\multicolumn{2}{|c|}{$\begin{array}{l}\mathrm{N}-\mathrm{NH}_{4}{ }^{+} \\
\left(\mathrm{kg} \mathrm{ha}^{-1}\right)\end{array}$}} & \multirow{3}{*}{$\begin{array}{c}\text { p- } \\
\text { value }\end{array}$} \\
\hline & \multirow[t]{2}{*}{ Year } & \multicolumn{2}{|c|}{$\left(\mathrm{kg} \mathrm{ha}^{-1}\right)$} & \multirow{2}{*}{$\begin{array}{c}\text { p- } \\
\text { value }\end{array}$} & & & & & & \\
\hline & & Cont & Fert & & Cont & Fert & & Cont & Fert & \\
\hline \multirow{2}{*}{ Granitic } & 2010 & 62.73 & 58.39 & 0.808 & 0.30 & 9.23 & 0.038 & & 9.16 & 0.482 \\
\hline & 2011 & 26.1 & 48.12 & 0.043 & 0.08 & 3.54 & 0.072 & 26.02 & 44.58 & 0.048 \\
\hline \multirow{2}{*}{ Sandy } & 2010 & 14.1 & 15.85 & 0 . & 1.32 & 9.70 & 6 & 12.82 & 6.15 & $0.058^{*}$ \\
\hline & 2011 & & 14.80 & & 1. & 2.31 & & 99 & 2.49 & 0.691 \\
\hline \multirow{3}{*}{ d clay } & 2010 & 29. & 23.60 & 0.7 & 0.6 & 6.83 & 0 . & 28.36 & 16.77 & 0.452 \\
\hline & 2011 & 49. & 1 & & 2.72 & 9.95 & & & 8.36 & \\
\hline & 2012 & 10 & 62.24 & 0.108 & 11.39 & 37.53 & 3 & 4.59 & 24.71 & 0.0 \\
\hline \multicolumn{11}{|c|}{ Net mineralization } \\
\hline \multirow{3}{*}{ Soil } & \multicolumn{4}{|c|}{ Mine ralization } & \multirow{2}{*}{\multicolumn{2}{|c|}{$\begin{array}{l}\text { Nitrification } \\
\left(\mathrm{kg} \mathrm{ha}^{-1}\right)\end{array}$}} & \multicolumn{4}{|c|}{ Ammonification } \\
\hline & \multirow[t]{2}{*}{ Year } & \multicolumn{2}{|c|}{$\left(\mathrm{kg} \mathrm{ha}^{-1}\right)$} & \multirow{2}{*}{$\begin{array}{c}\text { p- } \\
\text { value }\end{array}$} & & & \multirow{2}{*}{$\begin{array}{c}\mathrm{p}- \\
\text { value }\end{array}$} & \multicolumn{2}{|c|}{$\left(\mathrm{kg} \mathrm{ha}^{-1}\right)$} & \\
\hline & & $\mathrm{Co}$ & ert & & Cont & Fert & & Cont & ert & \\
\hline \multirow{2}{*}{ anitic } & v & 25 & 31.63 & 0.707 & -1 & 10 & 6 & 26.94 & 53 & 0.923 \\
\hline & 2011 & 29. & 88 & 0.799 & 0.16 & 2.88 & 4 & 29.11 & 29.41 & 0.979 \\
\hline \multirow[b]{2}{*}{ 正 } & 2010 & 11.3 & 10.31 & 0.469 & 0.3 & 5.61 & 0.061 & 11.00 & 4.69 & 0.233 \\
\hline & 2011 & 12.4 & 6.51 & 0.306 & -0.08 & 1.84 & 0.286 & 12.52 & 4.67 & 0.112 \\
\hline \multirow{3}{*}{ ed clay } & 2010 & -1.8 & 4.87 & 0.197 & -0.45 & 4.61 & 0.018 & -1.35 & 0.27 & 0.751 \\
\hline & 2011 & 29.12 & 74.27 & 0.104 & 5.20 & 34.22 & 0.058 & 23.92 & 40.05 & 0.434 \\
\hline & 2012 & 56.02 & 44.61 & 0.751 & 9.67 & 32.28 & 0.166 & 46.35 & 12.34 & 0.422 \\
\hline
\end{tabular}

\section{Discussion}

Effects of the fertilization over time interaction ( F X T) on the monthly availability of $\mathrm{N}$ and net mineralization $\left(\mathrm{N}-\left(\mathrm{NO}_{3}^{-}\right), \mathrm{N}-\left(\mathrm{NH}_{4}^{+}\right)\right.$) were observed several years after fertilization in granitic $(7 \mathrm{yr}$.) sandy (6 yr.) and red clay soils (3 yr.), which suggested that the processes did not respond similarly over time $(p<0.1)$ (Table 2). The long time response of the volume to fertilization reported in the granitic and sandy soils was opposite of that suggested by Miller (1981), who affirmed that the volume response to $\mathrm{N}$ fertilization is driven by $\mathrm{N}$ uptake immediately after fertilizer application rather than by increases in longterm $\mathrm{N}$ availability. In addition, Fife and Nambiar (1997) reported high $\mathrm{N}$ soil concentrations of $300 \mathrm{~kg}$ $\mathrm{N} \mathrm{ha}^{-1}$ in 7-year old Pinus radiata plantations during the months following to fertilization. However, 1 year 
later the concentrations decreased to their original values and equaled the plots without fertilization. Binkley and Reid (1985) suggest that the increments of $\mathrm{N}$ availability after fertilization are not common and occur when the amount of $\mathrm{N}$ retained in the system is large relative to the initial amount of N, which is similar to the process that occurs in granitic and sandy soils over time. These results are consistent with the results of other studies that have indicated the addition of $\mathrm{N}$ increases $\mathrm{N}$ mineralization (Raison et al., 1992; Carlyle, 1995). Raison et al. (1990) observed increases in net $\mathrm{N}$ mineralization and uptake after 4 years of fertilization with $400 \mathrm{~kg} \mathrm{~N} \mathrm{ha}^{-1}$ in a 10-year-old Pinus radiata stand.

We found that the $\mathrm{N}$ soil availability increased for more than 6 years after fertilization (fertilized treatments) and was equivalent to $\mathrm{N}$ uptake in the granitic and sandy soil. Similarly, Carlyle (1995) reported increases in $\mathrm{N}$ mineralization rates that were similar to $\mathrm{N}$ uptake rates in Pinus radiata stands after fertilization. The annual balance between gross $\mathrm{N}$ mineralization and immobilization was positive at all sites during the study period ( $\mathrm{N}$ net mineralization $>$ 0 ), despite some immobilization events (Figure 5). Paul et al. (2003) suggested that soils affect gross $\mathrm{N}$ mineralization and immobilization processes separately and differently in diverse soils and under the same conditions. Similarly, Raison et al. (1992) reported that $37 \%$ of $400 \mathrm{~kg} \mathrm{ha}^{-1}$ of applied $\mathrm{N}$ was immobilized during the next 8 months, and lab assays using $15 \mathrm{~N}$ indicated that soil microorganisms can immobilize a larger proportion of added N (Johnson et al., 2000) that could be released later. This result is related to large changes in the fertilization treatments (mineralization-immobilization) relative to the control treatment.

The nitrogen availability and net mineralization ranges were smallest in the sandy soil and greatest in the red clay soil (Figures 2, 4, 5). Ammonium content is related to parent material, texture, and clay content and composition, and is strongly retained in clay soils at cation exchange sites compared with silt and sand fractions of soil (Nieder et al., 2011), By contrast, nitrate is not retained and is easily leached (Johnson, 1992). Sandy soil have low organic matter contents with no cation exchange capacity (or very low) and are more susceptible to ammonium and nitrate leaching than granitic and red clay soil. By contrast, Paul et al. (2003) explained that several interrelated mechanisms, including reduced diffusion of soluble elements and reduced microbial mobility and access to the substrate, cause a decrease in microbial activity in many dry sandy soil, directly affect microbial growth, and are associated with processes such as $\mathrm{N}$ mineralization. Some field and laboratory studies (Quemada and Cabrera, 1997) have indicated that the effects of soil moisture on decomposition and net $\mathrm{N}$ mineralization vary with temperature. Thus, differences in $\mathrm{N}$ availability and rate mineralization can be explained by differences between the soil chemical and physical properties, soil moisture contents, and soil temperatures at different sites (O’Connell and Rance, 1999).

The cumulative annual available $\mathrm{N}-\left(\mathrm{NH}_{4}^{+}+\mathrm{NO}_{3}^{-}\right)$in the control treatment was less than $35 \mathrm{~kg} \mathrm{ha}^{-1} \mathrm{yr}^{-1}$ in the sandy and granitic soils, and both sites showed longterm volume responses to fertilization. This result suggests than the sites with $\mathrm{N}$ deficiencies have the chance to have a significant response to fertilization at mid rotation. By contrast, the red clay soil site had a cumulative available $\mathrm{N}-\left(\mathrm{NH}_{4}^{+}+\mathrm{NO}_{3}^{-}\right)$in the control treatment of more than $160 \mathrm{~kg} \mathrm{ha}^{-1} \mathrm{yr}^{-1}$, and no response to fertilization was observed (Table 1) although the $\mathrm{N}$ availability and mineralization rates increased in the fertilized treatments until 3 to 4 years after fertilization.

The monthly $\mathrm{N}$ availability differences between soil types could be explained by the soil temperature 
and moisture behavior (Table 3). Red clay soil had small changes on daily temperature compared with the others sites (Figure 1F), and sandy soil had the higher variations daily, and between winter and summer (Figure 1D). Respect to the soil moisture, the sandy soil had smaller WHCs, and the sandy and granitic soils had longer periods with soil moisture contents below PWP (Figures 1A, 1C). By contrast, the red clay soil sites had the largest WHC and were greater than PWP most of the time. The soil moisture content is highly relevant because microbial activity is enhanced in the soil under moist conditions, which results in greater mineralization rates and gross $\mathrm{N}$ immobilization processes (Paul et al., 2003).

Water and nutrient availability and its interactions effectively determine the magnitude of the response to additional fertilizer additions (Gonçalves et al., 1997; Lim et al., 2015). When fertilization is applied late during the rotation, the response may not occur unless fertilization is favored by an increase in soil available water, which occurs after thinning (Nambiar et al., 1984).

Monthly differences in soil moisture and temperature are related to the effects of the fertilization by time interaction (F X T) on monthly $\mathrm{N}$ availability and net mineralization. Most months with higher available $\mathrm{N}$ in the fertilized treatments than in the control occurred when the soil moisture content was greater than the PWP and the soil temperatures were greater than $11^{\circ} \mathrm{C}$ (mainly autumn and spring months) at all sites. A special event occurred in 2012 for the red clay soil when a rain fall no common occurred during the summer (January, February), and affected the soil moisture levels combined with high soil temperatures (Figures 1E, 1F). In this case, the $\mathrm{N}$ mineralization rates and $\mathrm{N}$ availability increased notably for these months (Figures 2G, 2H, 2I, 5G, $5 \mathrm{H}, 5 \mathrm{I})$. This finding is consistent with the fact that when temperature were high, high amounts of rain fall (and soil water moisture) occurred during the summer (January, February), early autumn (March, April), and spring months (October, November) in 2010 relative to the same months in 2011 (Figures 1A, 1C). This coincided with the reductions in $\mathrm{N}$ availability at all sites in 2011 (Figure 4). In the red clay soils, factors other than $\mathrm{N}$ limitations could potentially explain the lack of response after fertilization, regardless of the high $\mathrm{N}$ levels observed in the fertilized treatments.

\section{Conclusions}

The availability of $\mathrm{N}$ and the $\mathrm{N}$ uptake increments in the fertilized treatment were determinant on the long-term volume response for the granitic and sandy soils. Overall, $68.7 \%$ of the monthly $\mathrm{N}$ availability was explained by the soil temperature and moisture in the granitic and sandy soils. Also, the highest levels for fertilized treatments were observed during the spring (September-October) and autumn (April-May) months when the soil temperature and moisture were optimal for microbial activity.

Our results suggest that $\mathrm{N}-\left(\mathrm{NH}_{4}^{+}+\mathrm{NO}_{3}^{-}\right)$levels lower than $2 \mathrm{~kg} \mathrm{ha}^{-1}$ during the spring (September-October) and autumn months (April-May) or with $\mathrm{N}-\left(\mathrm{NO}_{3}^{-}\right)$ levels lower than $0.2 \mathrm{~kg} \mathrm{ha}^{-1}$ in any month may have significant potential responses to $\mathrm{N}$ fertilization during mid-rotation in Pinus radiata stands for granitic and sandy soil in Mediterranean climates. We recommend doing soil analysis for $\mathrm{N}-\left(\mathrm{NH}_{4}^{+}+\mathrm{NO}_{3}^{-}\right)$ in the referenced months, or estimating the $\mathrm{N}-\left(\mathrm{NH}_{4}^{+}+\right.$ $\mathrm{NO}_{3}^{-}$) content using the obtained model [6].

More research on the quantity and destination of nitrogen involved in different soil types and plant processes is necessary to monitor over time. Thus, the use of isotope labeling in future research is recommended. 


\section{Acknowledgements}

We acknowledge the Universidad de Concepción and the Forest Productivity Cooperative for providing scholarships to support the development of this thesis. Moreover, we acknowledge the National Commission for Scientific and Technological Research Chile (CONICYT) and the Chilean International Cooperation Agency (AGCI) for providing a scholarship (CONICYT-PCHA/Doctorado nacional/2013-63130285), and Bioforest SA (Forestal Arauco) and Forestal Mininco logistical and financial support and cooperation. Also, we thank to the Soil, Nutrition and Forest Productivity laboratory at Universidad de Concepción for providing necessary equipment for laboratory analyses.

\section{References}

Albaugh, T., Allen, H., Dougherty, P., Johnsen, K. 2004. Long term growth responses of loblolly pine to optimal nutrient and water resource availability. Forest Ecology and Management. 192, 3-19.

Alvear, M., Astorga, M., Reyes, F. 2008. Efecto de los residuos vegetales provenientes de dos tratamientos silvícolas en una plantación de Pinus radiata D. Don sobre los cambios estacionales de las actividades biológicas del suelo. Journal of soil science and plant nutrition. 8, 14-27.

Allen, H., Dougherty, P., Campbell, R. 1990. Manipulation of water and nutrients; practice and opportunity in southern US pine forests. Forest Ecology and Management. 30, 437-453.

Binkley, D., Reid, P. 1985. Long-term increase of nitrogen availability from fertilization of Douglasfir. Canadian Journal of Forest Research. 15, 723724.
Carlyle, J., 1995. Nutrient management in a Pinus radiata plantation after thinning: the effect of nitrogen fertilizer on soil nitrogen fluxes and tree growth. Canadian journal of forest research 25, 1673-1683.

Cartes, P., Jara, A., Demanet, R., Mora, M., 2009. Urease activity and nitrogen mineralization kinetics as affected by temperature and urea input rate in southern Chilean Andisols. Journal of soil science and plant nutrition 9, 69-82.

Fife, D., Nambiar, E., 1997. Changes in the canopy and growth of Pinus radiata in response to nitrogen supply. Forest Ecology and Management 93, 137-152.

Fox, T., Allen, H., Albaugh, T., Rubilar, R., Carlson, C., 2007. Tree nutrition and forest fertilization of pine plantations in the southern United States. Southern Journal of Applied Forestry 31, 5-11.

FPC, 2013. Mid-rotation fertilization on radiate pine. Forest Productivity Cooperative, Research Summaries Regionwide 13, 167.

Gonçalves, J., Barros, N., Nambiar, E., Novais, R., Brown, A., 1997. Soil and stand management for short-rotation plantations. Management of soil, nutrients and water in tropical plantation forests., 379-417.

Gurlevik, N., Kelting, D., Allen, H., 2004. Nitrogen mineralization following vegetation control and fertilization in a 14-year-old loblolly pine plantation. Soil Science Society of America Journal. 68, 272-281.

Johnson, D., 1992. Nitrogen retention in forest soils. Journal of Environmental Quality 21, 1-12.

Johnson, D., Cheng, W., Burke, I., 2000. Biotic and abiotic nitrogen retention in a variety of forest soils. Soil Science Society of America Journal. 64, 1503-1514. 
Johnson, D., Turner, J., 2014. Nitrogen budgets of forest ecosystems: A review. Forest Ecology and Management 318, 370-379.

Khanna, P., Raison, R., 2013. In situ core methods for estimating soil mineral-N fluxes: Re-evaluation based on 25 years of application and experience. Soil Biology and Biochemistry 64, 203-210.

Lim, H., Oren, R., Palmroth, S., Tor-ngern, P., Mörling, T., Näsholm, T., Lundmark, T., Helmisaari, H., Leppälammi, J., Linder, S., 2015. Inter-annual variability of precipitation constrains the production response of boreal Pinus sylvestris to nitrogen fertilization. Forest Ecology and Management 348, 31-45.

Littell, R.C., Stroup, W.W., Milliken, G.A., Wolfinger, R.D., Schabenberger, O., 2006. SAS for mixed models. SAS institute.

Miller, H., 1981. Forest fertilization: some guiding concepts. Forestry 54, 157-167.

Mulvaney, R., Sparks, D., Page, A., Helmke, P., Loeppert, R., Soltanpour, P., Tabatabai, M., Johnston, C., Sumner, M., 1996. Nitrogen-inorganic forms. Methods of soil analysis. Part 3-chemical methods., 1123-1184.

Nambiar, E., Squire, R., Sands, R., Will, G., 1984. Manipulation of water and nutrients in plantations of fast growing species. In, Site and Productivity of Fast Growing Plantations. Proceedings IUFRO Symp. Forestry Research Institute. Department of Enviroment Affairs. Pretoria, South Africa, pp. 489-506.

Nieder, R., Benbi, D., Scherer, H., 2011. Fixation and defixation of ammonium in soils: a review. Biology and fertility of Soils 47, 1-14.

O’Connell, A., Rance, S., 1999. Predicting nitrogen supply in plantation eucalypt forests. Soil Biology and Biochemistry 31, 1943-1951.
Paul, K., Polglase, P., O'Connell, A., Carlyle, J., Smethurst, P., Khanna, P., 2003. Defining the relation between soil water content and net nitrogen mineralization. European Journal of Soil Science 54, 39-48.

Perreault, S., Chokmani, K., Nolin, M., Bourgeois, G., 2013. Validation of a Soil Temperature and Moisture Model in Southern Quebec, Canada. Soil Science Society of America Journal 77, 606-617.

Pulgarín, G., Naranjo, J., 2005. Determinación de Nitratos y amonio en muestras de suelo mediante el uso de electrodos selectivos. Revista Facultad Nacional de Agronomía-Medellín 58.

Quemada, M., Cabrera, M., 1997. Temperature and moisture effects on $\mathrm{C}$ and $\mathrm{N}$ mineralization from surface applied clover residue. Plant and soil 189, 127-137.

Raison, R., Connell, M., Khanna, P., 1987. Methodology for studying fluxes of soil mineral-N in situ. Soil Biology and Biochemistry 19, 521-530.

Raison, R., Connell, M., Khanna, P., Falkiner, R., 1992. Effects of irrigation and nitrogen fertilisation on fluxes of soil mineral nitrogen in a stand of Pinus radiata. Forest ecology and management 52, 43-64.

Raison, R., Khanna, P., Connell, M., Falkiner, R., 1990. Effects of water availability and fertilization on nitrogen cycling in a stand of Pinus radiata. Forest Ecology and Management .30, 31-43.

Richards, L., Fireman, M., 1943. Pressure-plate apparatus for measuring moisture sorption and transmission by soils. Soil Science 56, 395-404.

Richter, D., Markewitz, D., Heine, P., Jin, V., Raikes, J., Tian, K., Wells, C., 2000. Legacies of agriculture and forest regrowth in the nitrogen of oldfield soils. Forest Ecology and Management 138, 233-248. 
Rubilar, R., Albaugh, T., Allen, H., Alvarez, J., Fox, T., Stape, J., 2013. Foliage development and leaf area duration in Pinus radiata. Forest Ecology and Management. 304, 455-463.

SAS, I., 2009a. JMP®. Version 8. In. Institute Inc Cary, North Carolina.

SAS, I., 2009b. Statistical Analysis System ${ }^{\circledR}$, Versión 9.2. In. Institute Inc Cary, North Carolina.

Schepers, J., Raun, W., 2008. Nitrogen in agricultural systems. ASA-CSSA-SSSA.
Stolpe, N., 2006. Descripciones de los principales suelos de la VIII Región de Chile. Publicaciones Departamento de Suelos y Recursos Naturales, Universidad de Concepción, Chillán, Chile.

Turner, J., Lambert, M.J., 1986. Nutrition and nutritional relationships of Pinus radiata. Annual review of ecology and systematics, 325-350.

Zerpa, J., Allen, H., Campbell, R., Phelan, J., Duzan, H., 2010. Influence of variable organic matter retention on nutrient availability in a 10 -year-old loblolly pine plantation. Forest ecology and management 259, 1480-1489. 